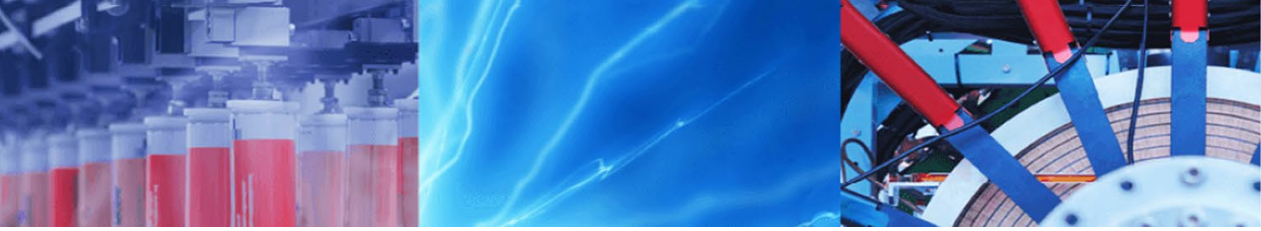

Research Article

\title{
Bioindicators and nutrient availability through whole soil profile under orange groves after long-term different organic fertilizations
}

\author{
Eristanna Palazzolo ${ }^{1}$ - Vito Armando Laudicina ${ }^{1} \cdot$ Giancarlo Roccuzzo $^{2} \cdot$ Maria Allegra $^{3} \cdot$ Biagio Torrisi $^{3}$. \\ Anna Micalizzi ${ }^{1} \cdot$ Luigi Badalucco $^{1}$ (i)
}

(c) Springer Nature Switzerland AG 2019

\begin{abstract}
We investigated long-term (18 years) effects of three organic (cow manure (CM), poultry manure (PM), compost from agro-industry orange wastes (OW)) and one inorganic fertilization (IF) on various soil biological indicators (microbial biomass C, soil respiration, total phospholipid fatty acids (PLFAs), total bacteria, Gram-positive and Gram-negative bacteria and fungi) and nutrient contents (total and extractable organic $\mathrm{C}$, total and mineral $\mathrm{N}$, available $\mathrm{P}$ and $\mathrm{K}$ ) along the profile of a Typic Haplustept under orange Mediterranean orchards. All fertilizers were added on the same $\mathrm{N}$ content basis (190 kg N ha ${ }^{-1}$ per year). Variables related to carbon cycling gradually worsened with depth, regardless of treatment, but at any soil depth they improved according to IF $<\mathrm{PM}<\mathrm{OW}<\mathrm{CM}$. Similarly, mineral nutrient availability decreased with increasing soil depth, according to $\mathrm{CM}>\mathrm{OW}>\mathrm{PM}>\mathrm{IF}$. Organic manures favoured Gram-negative bacteria, especially between 35 and $55 \mathrm{~cm}$ depth, whereas Gram-positive bacteria flourished better under inorganic fertilization up to $55 \mathrm{~cm}$. Organic fertilizers increased microbial biomass C, compared with IF, with CM being the most efficient, i.e. inducing the greatest $C$ use efficiency, in turn coupled with a greater amount of fungi compared to bacteria. This is crucial from the environmental viewpoint, since fungi better contribute to soil $\mathrm{C}$ storage. PLFAs signatures of microbial communities reflected the differences in resources availability determined by soil depth and fertilizer type; indeed, fungi and Gramnegative bacteria responded more promptly to nutrient contents than other microbial groups. Oligotrophic conditions in deeper soil horizons increased the metabolic quotient, an indicator of stress conditions.
\end{abstract}

Keywords Farmyard manure · Orange waste compost · Mineral fertilization · Subsoil carbon · Bioindicators · Semiarid Mediterranean climate

\section{Introduction}

Soils are usually added with organic fertilizers to improve their physical, chemical and biological properties, thus optimizing plant growth and preserving soil conservation [1, 2]. In contrast to inorganic fertilizers, nutrients immobilized into organic fertilizers must be mineralized by soil micro-organisms before becoming available to plants through root absorption. The long-term organic management of agricultural soils positively influences soil properties since the addition of organic fertilizers promotes the organic matter accumulation in soil by favouring $C$ pools with slower turnover times [3-5]. On the contrary, the addition of readily decomposable organic substrates may also trigger off the decomposition of native soil organic matter through a priming effect devoted to reduce the $\mathrm{N}$ deficiency for microbial biomass $[1,6,7]$.

$\triangle$ Luigi Badalucco, luigi.badalucco@unipa.it| ${ }^{1}$ Department of Agricultural, Food and Forestry Sciences, University of Palermo, Viale delle Scienze, Building 4, 90128 Palermo, Italy. ${ }^{2}$ Research Centre for Olive, Citrus and Tree Fruit, Council for Agricultural Research and Economics (CREA), Via la Canapona 1 bis, 47121 Forlì, Forlì, Italy. ${ }^{3}$ Research Centre for Olive, Citrus and Tree Fruit, Council for Agricultural Research and Economics (CREA), Corso Savoia 190, 95024 Acireale, Italy.

SN Applied Sciences (2019) 1:468 | https://doi.org/10.1007/s42452-019-0479-3

Received: 4 January 2019 / Accepted: 10 April 2019 / Published online: 19 April 2019 
Although it is well established that long-term (> 10 years) organic fertilization enhances soil organic matter (SOM) and nutrients availability in topsoil (generally less than the first $30 \mathrm{~cm}$ ) $[8,9]$, the impact of organic fertilizers along the soil profile is still controversial and not widely known [10, 11]. Organic fertilizers applied to topsoil can affect carbon and nutrients availability of deeper soil horizons through transport of dissolved organic matter. Therefore, to understand how organic fertilizers affect SOM dynamics and nutrient availability also in deeper soil horizons, it is of great importance, especially for those crops whose roots extend down more than $30 \mathrm{~cm}$, such as tree crops, with subsequent increase in rhizodepositions [12].

With regard to inorganic $\mathrm{N}$ fertilization, it may have either positive or negative effects not only on soil organic $C$ accumulation but also on its fractions [13-15]. On the one hand, $\mathrm{N}$ fertilization has proven to increase the SOC through increasing biomass production and hence $C$ inputs to the soil [16]. On the other hand, Khan et al. [17] and Mulvaney et al. [18] suggested that the loss of SOC from soils may occur in response to synthetic $\mathrm{N}$ fertilizers as they promote the decomposition of native SOM and crop residues [19].

The effects of organic fertilizers on microbial community composition and activities are even less known, especially in deeper horizons $[20,21]$. Farmyard manure and inorganic fertilizers can have both positive and negative effects on microbial biomass and activities [22]. Generally, organic manure markedly increases soil microbial biomass carbon $(M B C)$, microbial quotient $(M Q)$, i.e. $M B C /$ SOC ratio and also soil respiration (SR) [3]. MBC increases due to rapid immobilization of simple organic substrates held within manure, while SR increases to their rapid mineralization [11].

Deep soils have a high potential in storing carbon [23] and, therefore, any agricultural management stimulating or repressing microbial activity, biomass and composition in subsoils impacts $C$ and nutrients dynamics because micro-organisms drive the turnover of SOM [24]. Soil microbial communities are not uniformly dispersed throughout soil profile, but reflect patches of available resources $[25,26]$. Organic substrates and microbial biomass and activity, generally, decline with increasing soil depth $[27,28]$. However, when soil quality indicators were normalized to microbial biomass, specific enzyme activities showed either similar values throughout soil profile or even increased with depth [24].

As the agronomical impact of long-term organic fertilization along the soil profile is not well known so far, especially under orchards in semiarid Mediterranean environment, the aim of this study was to investigate the effects of three long-term (18 years) organic fertilizations (cow manure, poultry manure and compost from agroindustry orange wastes) on various SOM pools, nutrients availability and microbial community composition along the profile of a Typic Haplustept under orange orchards in semiarid Mediterranean conditions. An inorganically (NPK) fertilized orange orchard soil profile was also investigated for comparison. We hypothesized that: (1) the impact of long-term organic fertilization on chemical, biochemical and microbial soil properties would vary with both fertilizer type and soil depth, especially in the deeper soil horizons (below $30 \mathrm{~cm}$ ) and (2) the interaction between fertilizer type and soil depth would uncouple SOM pools and microbial groups abundance.

\section{Materials and methods}

\subsection{Study site, experimental design and soil sampling}

The study was performed in an experimental site designed for orange orchards ( $\left.37^{\circ} 20^{\prime} 22.84^{\prime \prime} \mathrm{N} ; 14^{\circ} 53^{\prime} 32.02^{\prime \prime} \mathrm{E}\right)$ of Italian Council for Research in Agriculture (CREA, Catania province, Sicily, Italy). Average annual rainfall and air temperature during last 25 years were $350 \mathrm{~mm}$ and $18.7^{\circ} \mathrm{C}$, respectively. The climate is typical Mediterranean (Köppen-Geiger's classification). Since 1995, orchards have been annually fertilized inorganically (IF) or organically with: 4-month-aged solid cow manure (CM) from dairy; 7-month-aged solid poultry manure (PM); and 5-monthaged compost (OW) from orange juice processing wastes (75\%) and garden cleaning (25\%). Agro-industrial wastes consisted of about $60 \%$ peel, $30 \%$ pulp and $10 \%$ pips, while garden cleaning contained triturated pruning residues and mown grasses. All fertilizations were calibrated to the same $\mathrm{N}$ inputs (190 kg N per hectare); due to the different chemical nature of fertilizers, added amounts of $C, P$ and $K$ varied among fertilizations. Table 1 shows main chemical properties of organic fertilizers, while Table 2 shows annual $\mathrm{C}, \mathrm{N}, \mathrm{P}$ and $\mathrm{K}$ inputs for all fertilizations.

Three randomized orchards (each $50 \mathrm{~m} \times 30 \mathrm{~m}$ ) for each treatment were selected (12 in total); then, five equidistant plots (each $2 \mathrm{~m} \times 2 \mathrm{~m}$ ) were diagonally marked off for each orchard to totally explore it. A soil profile was opened in spring 2013 in one-by-five plots of each orchard. According to the sequence of genetic horizons [29] of the respective opened profile, a single soil sample, constituted by five subsamples (one for each plot), was collected for each horizon and for each orchard ( $n=3$, four treatments, five horizons for each profile, sixty soil samples in total). In the plots used for opening the profiles, soil subsamples were collected by a shovel, while in the other four plots for each treatment, the soil subsamples were collected by an auger, 
Table 1 Chemical composition of applied aged farmyard manures and compost from orange wastes. Data are expressed on dry weight basis $\left(24 \mathrm{~h}\right.$ at $\left.105^{\circ} \mathrm{C}\right)$

\begin{tabular}{lllllrr}
\hline Fertilizer & TOC (\%) & TN (\%) & TP (\%) & TK (\%) & RH (\%) & TOC/TN \\
\hline Poultry manure (PM) & 35.5 & 4.0 & 0.81 & 1.04 & 17 & 8.9 \\
Orange waste compost (OW) & 37.0 & 2.1 & 0.44 & 1.65 & 40 & 17.6 \\
Cow manure (CM) & 29.0 & 1.5 & 0.52 & 0.88 & 30 & 19.3
\end{tabular}

$T O C$ total organic carbon; $T N$ total nitrogen; $T P$ total phosphorous; $T K$ total potassium; $R H$ relative humidity on wet weight basis

Table 2 Amounts $\left(\mathrm{kg} \mathrm{ha}^{-1}\right)$ of nutrients supplied each year in the four treatments. Data are expressed on dry weight basis $(24 \mathrm{~h}$ at $105^{\circ} \mathrm{C}$ ) of fertilizer

\begin{tabular}{lllll}
\hline Fertilizer & TOC & TN & TP & TK \\
\hline Inorganic (IF) & - & 190 & 25.5 & 66.4 \\
Poultry manure (PM) & 1550 & 190 & 46.9 & 78.9 \\
Orange waste compost (OW) & 2760 & 190 & 12.2 & 41.5 \\
Cow manure (CM) & 1780 & 190 & 48.9 & 99.6 \\
\hline
\end{tabular}

TOC total organic carbon; TN total nitrogen; TP total phosphorous; TK total potassium

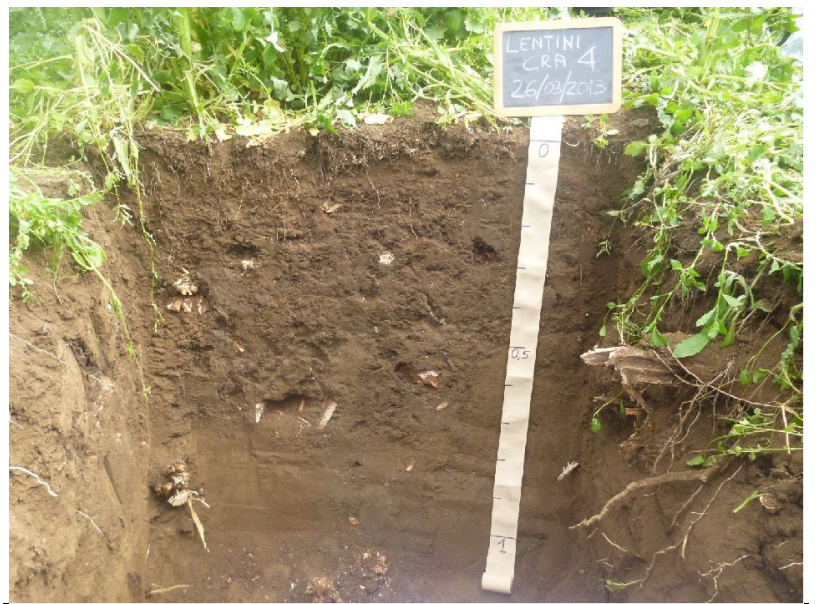

Soil profile field description [29-31]

Horizon Depth Boundary Moist color Structure Roots Consistence $\mathrm{cm}$ dry moist

rhiA $\quad 0-12 \quad$ Clear $\quad 5$ YR 4/3 sbk,me, $1 \quad$ f, m, 2 sh $\quad$ fr maA 12-35 Diffuse 7.5YR 4/4 abk, me, 2 f, m, $3 \mathrm{mh}$ sh $\mathrm{AB} \quad 35-55$ Diffuse $7.5 \mathrm{YR} 4 / 4$ abk, me, $2 \mathrm{~m}, \mathrm{c}, 2 \mathrm{mh} \mathrm{mh}$ Bw 55-75 Gradual 7.5YR 5/3 ma c, m, $1 \mathrm{~h} \quad \mathrm{mh}$ BC $\quad 75-90$ Gradual 7.5 YR $5 / 2$ ma $\quad$ c, $1 \quad \mathrm{mh} \quad \mathrm{mh}$ C $>90$ Gradual 7.5YR 5/2 ma $\quad \mathrm{mh} \mathrm{mh}$

Fig. 1 Soil profile field description. Soil profile opened in the cow manure treatment. Structure: $a b k$ angular blocky, sbk subangular blocky, ma massive; 1 moderate, 2 strong; $f$ fine, me medium. Roots: 1 few, 2 common, 3 many; $f$ fine, $m$ medium, $c$ coarse. Consistence: sh slightly hard, $m h$ moderately hard, $h$ hard, fr friable

correspondingly to the depth of genetic horizons of the opened profile. Figure 1 shows the field description of the soil profile of one-by-three orchards of CM treatment. Soil profiles were opened, and samples were collected 1 year after the last fertilizer application (spring 2012) to minimize effects of supplied fresh nutrients.

Field-moist soil samples were divided into two aliquots, one freshly sieved at $4 \mathrm{~mm}$, rewetted up to $50 \%$ of water holding capacity (WHC) and stored at $4{ }^{\circ} \mathrm{C}$ in scantly sealed polyethylene bottles prior to soil biochemical analyses, while the second air-dried, sieved $(<2 \mathrm{~mm})$ and stored in sealed polyethylene bottles at $4{ }^{\circ} \mathrm{C}$ prior to soil chemical analyses.

\subsection{Physical and chemical analyses of soil samples}

Physical and chemical soil properties were determined using standard, internationally recognized methods. Bulk density (BD) was determined from undisturbed samples using a steel cylinder ( $5 \mathrm{~cm}$ diameter, $5 \mathrm{~cm}$ height); texture (sand, 2-0.02 mm; silt, 0.02-0.002 mm; clay, $<0.002 \mathrm{~mm}$ ) by pipette method after shaking slurries for $2 \mathrm{~h}$ in $\left(\mathrm{NaPO}_{3}\right)_{6}$ and $\mathrm{Na}_{2} \mathrm{CO}_{3}$, without removing organic matter; soil $\mathrm{pH}$ by glass membrane electrode in distilled water (soil/ water ratio $1: 2.5(\mathrm{w} / \mathrm{v}))$; total carbonates content by the Dietrich-Fruehling's calcimeter; soil electrical conductivity $(E C)$ in distilled water (soil/water ratio 1:5 (w/v)); cation exchange capacity (CEC) by Mehlich's method using $\mathrm{BaCl}_{2}$ and triethanolamine at $\mathrm{pH} 8.2$ as extracting solution; total organic $\mathrm{C}$ (TOC) and total $\mathrm{N}$ (TN) by wet digestion $\left(\mathrm{H}_{2} \mathrm{SO}_{4}\right)$-oxidation $\left(\mathrm{K}_{2} \mathrm{Cr}_{2} \mathrm{O}_{7}\right)$ and Kjeldahl digestion, respectively; soil available $\mathrm{P}$ according to Olsen et al. [30]; and soil available $\mathrm{K}$ as sum of water extractable potassium (10 g soil: $50 \mathrm{~mL}$ distilled water) and exchangeable potassium ( $2 \mathrm{~g}$ of soil: $25 \mathrm{~mL} \mathrm{BaCl}_{2}$-triethanolamine at $\mathrm{pH}$ 8.2).

\subsection{Determination of soil biochemical properties and main microbial groups}

Microbial biomass $C$ (MBC) was determined by fumigationextraction method [31]; it corresponded to the difference between organic $C$ extracted from fumigated and unfumigated samples, multiplied by 2.64 . The concentration of $\mathrm{K}_{2} \mathrm{SO}_{4}$-extractable $\mathrm{C}$ from unfumigated soil was a proxy of available C [32]. Ammonium and nitrate concentrations 
were also determined on soil $\mathrm{K}_{2} \mathrm{SO}_{4}$ extracts by indophenol blue and chromotropic acid colorimetric methods, respectively. Microbial quotient (MQ) was calculated as the percentage of TOC present as MBC.

Soil respiration (SR) corresponded to cumulative $\mathrm{CO}_{2}$ evolved from incubated soil $\left(24 \mathrm{~h}, 50 \% \mathrm{WHC}, 25^{\circ} \mathrm{C}\right)$ and metabolic quotient $\left(\mathrm{qCO}_{2}\right)$, i.e. specific respiration, was calculated as $\mathrm{mg} \mathrm{CO}_{2}-\mathrm{Ch}^{-1} \mathrm{~g}^{-1} \mathrm{MBC}$ [24].

PLFAs were extracted and analysed according to modified Bligh and Dyer's method [33]. Nonadecanoic acid methyl ester was the internal standard for FAMEs quantification. Peaks were identified by comparison with retention times of known standards (Supelco BAME mix 47080-U; Supelco 37 Component FAME mix 47885-U). FAs with less than 14 or more than 19 carbon atoms were neglected as originating from non-microbial sources. The FAs i15:0, a15:0, 15:0, i16:0, i17:0, 17:0, cy17:0, 18:1 $\omega 7$, cy19:0 represented bacterial biomass, while $18: 2 \omega 6,9$ corresponded to fungal biomass [34]. The FAs i15:0, a15:0, i16:0, i17:0 represented Gram-positive bacteria while 18:1 $\omega 7$, cy17:0 and cy19:0 Gram-negative bacteria [35].

\subsection{Statistical analyses}

Data were expressed on oven-dry weight soil basis $\left(105^{\circ} \mathrm{C}\right.$, $24 \mathrm{~h}$ ). As the experimental site was homogeneous pedogenically, i.e. the opened four profiles (one for each treatment) resulted highly comparable as all showed the same five horizons (Fig. 1), we opted for not considering the soil depth as a main experimental factor, thus excluding the two-way ANOVA. Consequently, significant differences in soil properties at the same genetic horizon (depth) induced by different fertilizers or among genetic horizons within the same soil profile (fertilizer) were assessed by one-way ANOVA (fertilizer type or genetic horizon as single factors, respectively) followed by Tukey's HSD post hoc test $(p<0.05)$. Normal distribution and variance homogeneity of data were checked by Kolmogorov-Smirnov goodness of fit and Levene's tests, respectively. Statistical analyses were run using Statgraphics 15.0.

\section{Results}

\subsection{Physical and chemical properties of soil}

The sequence of genetic horizons ( $A p(r h i A+m a A)-$ $A B-B w-B C-C)$ was determined following both Zanella et al. [36, 37] and Soil Survey Staff [29], and it was the same throughout all soil profiles within the experimental site. For example, rhiA horizon in CM treatment was $12 \mathrm{~cm}$ in depth, and it had a sub-angular blocky structure and was well permeated by roots, mainly belonging to the spontaneous herbaceous vegetation (Fig. 1). The maA horizon $(12-35 \mathrm{~cm})$ had an angular blocky structure and was permeated by few to some roots belonging to both herbaceous vegetation and orange trees. The $A B$ horizon $(35-55 \mathrm{~cm})$ showed features similar to those of $\mathrm{maA}$ horizon, except for the roots belonging to only orange trees. The thickness of Bw horizon was $20 \mathrm{~cm}$, i.e. from 55 to $75 \mathrm{~cm}$ of depth, had some orange roots but less than the overlying horizon. The BC horizon $(75-90 \mathrm{~cm})$ had a massive soil structure, and only scant roots were present, becoming even more massive below $90 \mathrm{~cm}$ (C horizon; Fig. 1).

Soil bulk density (BD) significantly increased with depth, averaging from $1.06 \mathrm{~g} \mathrm{~cm}^{-3}$ in Ap horizon to 1.15 in $\mathrm{C}$ horizons, but did not differ among treatments regardless of depth (data not shown). Soil texture shifted from sand-silty and clay-sandy to sandy along profiles. Soil EC was generally the least in rhiA horizon and, like BD, was not affected by fertilizers type (Table 3). Total carbonates generally increased with soil depth. Soil pH also generally slightly increased with soil depth and was not significantly affected by treatments. Cation exchange capacity among treatments was highest in $\mathrm{CM}$ and $\mathrm{OW}$ while, among horizons, highest always in maA or AB ones (Table 3 ).

Regardless of the fertilizers supplied, $\mathrm{C}$ and $\mathrm{N}$ pools as well as available $P$ and $K$ decreased by increasing soil depth. Topsoils (Ap horizons) fertilized with IF and PM had TOC contents about $25 \%$ lower than soils fertilized with OW and CM. By increasing soil depth, such a difference among treatments diminished, but they were still significant (Fig. 2a). Extractable organic C (EOC), similar to TOC, increased always as $\mathrm{IF}<\mathrm{PM}<\mathrm{OW}<\mathrm{CM}$ also in the deepest horizons ( $>55 \mathrm{~cm}$ ) (Fig. 2b). Remarkably, the EOC ratio between IF (the poorest in EOC) and CM (the richest in EOC) treatments decreased with soil depth. Indeed, in Ap horizon, it was 0.44 , whereas in Bw horizon it lowered to 0.15 (Fig. 2b).

Similar to TOC, TN gradually decreased with depth, regardless of fertilizers, and it was $25 \%$ higher with $\mathrm{CM}$ but in Ap horizon only (Fig. 3a). Mineral $\mathrm{N}\left(\mathrm{NH}_{4}{ }^{+}\right.$plus $\left.\mathrm{NO}_{3}{ }^{-}\right)$ content was always higher with organic fertilizers, compared to IF, and also decreased with soil depth. Remarkably, mineral $\mathrm{N}$ content in Ap horizon with $\mathrm{CM}$ more than doubled that with IF (Fig. 3b).

In the topsoils, total organic $C$ to total $\mathrm{N}$ ratio $(\mathrm{C} / \mathrm{N})$ ranged from 13 to 19 and was the lowest in IF treatment and the highest in OW. In the subsoils, such a ratio did not show a clear trend among treatments, except at $A B$ horizon which was the lowest for PM. At lower depths, the $\mathrm{C} / \mathrm{N}$ ratio did not change appreciably among treatments (Fig. 4). Available $P$ in soil fertilized with $C M$ and PM was in average more than twice as much as with IF and OW (Fig. 5a) also in the deepest horizons. Available $\mathrm{K}$ in the 
Table 3 Edaphic properties of soils fertilized with four different fertilizers (IF, inorganic fertilizer; PM, poultry manure; OC, orange waste compost; $\mathrm{CM}$, cow manure)

\begin{tabular}{|c|c|c|c|c|c|c|c|c|}
\hline Fertilizer & Horizon & Sand \% & Silt \% & Clay \% & $\mathrm{PH}$ & $\mathrm{EC} \mathrm{dS} \mathrm{m}^{-1}$ & $\mathrm{TC} \mathrm{g} \mathrm{kg}{ }^{-1}$ & CEC cmol $\mathrm{cm}_{(+)} \mathrm{kg}^{-1}$ \\
\hline IF & rhiA & $63 \mathrm{Aa}$ & 19 ABab & $18 \mathrm{Aa}$ & $7.8 \mathrm{Ba}$ & $0.7 \mathrm{Ca}$ & $4.5 \mathrm{ABb}$ & $18 \mathrm{BC}$ \\
\hline IF & $\mathrm{maA}$ & $63 \mathrm{Aa}$ & $19 \mathrm{ABa}$ & $18 \mathrm{Ab}$ & $8.1 \mathrm{ABa}$ & $1.2 \mathrm{ABa}$ & $3.6 \mathrm{Bb}$ & $26 \mathrm{Ab}$ \\
\hline IF & $A B$ & $63 \mathrm{Aa}$ & $25 \mathrm{Aa}$ & $12 \mathrm{ABb}$ & $8.1 \mathrm{AB}$ & $0.9 \mathrm{BCb}$ & $2.7 \mathrm{Bb}$ & $20 \mathrm{ABC}$ \\
\hline IF & Bw & $73 \mathrm{Ba}$ & $15 \mathrm{Bab}$ & $12 \mathrm{ABb}$ & $8.4 \mathrm{Aa}$ & $1.3 \mathrm{Aa}$ & 7.6 Aa & $16 \mathrm{BCb}$ \\
\hline IF & $\mathrm{BC}$ & $70 \mathrm{Bb}$ & $20 \mathrm{ABa}$ & $10 \mathrm{Bb}$ & $8.5 \mathrm{Aa}$ & 1.4 Aa & $8.1 \mathrm{Aa}$ & $12 \mathrm{Ca}$ \\
\hline PM & rhiA & $57 \mathrm{Aab}$ & $21 \mathrm{Aa}$ & $22 \mathrm{Aa}$ & $7.8 \mathrm{ABa}$ & 1.0 ABa & $2.7 \mathrm{Bb}$ & $15 \mathrm{Bc}$ \\
\hline PM & $\mathrm{maA}$ & $58 \mathrm{Aa}$ & $21 \mathrm{Aa}$ & 21 Aab & 7.9 ABa & $1.4 \mathrm{Aa}$ & $4.5 \mathrm{ABb}$ & $23 \mathrm{Ab}$ \\
\hline PM & $A B$ & $63 \mathrm{Ba}$ & $13 \mathrm{Bb}$ & $24 \mathrm{Aa}$ & $7.7 \mathrm{Ba}$ & $0.7 \mathrm{Bb}$ & $3.3 \mathrm{Bb}$ & $18 \mathrm{ABC}$ \\
\hline PM & Bw & $73 \mathrm{Ca}$ & $6 \mathrm{BC}$ & $21 \mathrm{Aa}$ & $8.3 \mathrm{Aa}$ & $1.2 \mathrm{Aa}$ & $7.1 \mathrm{Aa}$ & $17 \mathrm{ABb}$ \\
\hline PM & $B C$ & $69 \mathrm{BCb}$ & $10 \mathrm{Bbc}$ & $21 \mathrm{Aa}$ & $8.4 \mathrm{Aa}$ & $1.3 \mathrm{Aa}$ & 7.8 Aa & $15 \mathrm{Ba}$ \\
\hline OW & rhiA & $63 \mathrm{Aa}$ & $15 \mathrm{ABb}$ & $22 \mathrm{Aa}$ & $7.8 \mathrm{Ba}$ & $0.9 \mathrm{Ba}$ & $2.7 \mathrm{Cc}$ & $26 \mathrm{Bb}$ \\
\hline OW & $\mathrm{maA}$ & $63 \mathrm{Aa}$ & $10 \mathrm{Bb}$ & $27 \mathrm{Aa}$ & 7.9 ABa & $1.4 \mathrm{Aa}$ & $2.7 \mathrm{Cc}$ & $36 \mathrm{Aa}$ \\
\hline OW & $A B$ & $60 \mathrm{Aa}$ & $18 \mathrm{ABab}$ & $22 \mathrm{Aa}$ & $8.0 \mathrm{AB}$ & $1.7 \mathrm{Aa}$ & $5.7 \mathrm{BCbc}$ & $42 \mathrm{Aa}$ \\
\hline OW & Bw & $68 \mathrm{Ba}$ & $20 \mathrm{Aa}$ & $12 \mathrm{Bb}$ & $8.2 \mathrm{Aa}$ & $1.3 \mathrm{Aa}$ & 8.2 ABab & $29 \mathrm{Ba}$ \\
\hline OW & $B C$ & $70 \mathrm{Bb}$ & 15ABab & $15 \mathrm{Bab}$ & $8.5 \mathrm{Aa}$ & $1.3 \mathrm{Aa}$ & $11.1 \mathrm{Aa}$ & $13 \mathrm{Cba}$ \\
\hline CM & rhiA & $53 \mathrm{Ab}$ & $25 \mathrm{Aa}$ & $22 \mathrm{ABa}$ & $8.0 \mathrm{Aa}$ & $0.9 \mathrm{Ba}$ & $2.7 \mathrm{Cc}$ & $34 \mathrm{Ba}$ \\
\hline $\mathrm{CM}$ & $\mathrm{maA}$ & $58 \mathrm{Aa}$ & $15 \mathrm{Bab}$ & $27 \mathrm{Aa}$ & $8.1 \mathrm{Aa}$ & $1.4 \mathrm{Aa}$ & $3.6 \mathrm{BCc}$ & $41 \mathrm{Aa}$ \\
\hline CM & $A B$ & $58 \mathrm{Aa}$ & $20 \mathrm{ABa}$ & $22 \mathrm{ABa}$ & $8.1 \mathrm{Aa}$ & $1.4 \mathrm{Aa}$ & $6.3 \mathrm{Bb}$ & $31 \mathrm{BCb}$ \\
\hline CM & Bw & $68 \mathrm{Ba}$ & $10 \mathrm{BCbc}$ & $22 \mathrm{ABa}$ & $8.3 \mathrm{Aa}$ & $1.3 \mathrm{Aa}$ & 13.4 Aa & $25 \mathrm{CDa}$ \\
\hline CM & $B C$ & $78 \mathrm{Ca}$ & $5 \mathrm{Cc}$ & 17 Bab & $8.4 \mathrm{Aa}$ & $0.9 \mathrm{Bb}$ & $15.2 \mathrm{Aa}$ & $19 \mathrm{Da}$ \\
\hline
\end{tabular}

Different upper-case letters indicate significant differences at $P<0.05$ among genetic horizons (depths) within the same soil profile; different lower-case letters indicate significant differences at $P<0.05$ among soil profiles (fertilizers) at the same depth

Sand $0.02<\varnothing<2 \mathrm{~mm}$; silt $0.002<\varnothing<0.02 \mathrm{~mm}$; clay $0.002<\varnothing ; \mathrm{pH}$ in water (1:2.5, soil:water); $E C$ electrical conductivity in soil extract (1:5, soil:water); TC total carbonates; CEC cation exchange capacity upper two horizons did not show a clear trend among treatments, whereas in the deepest one $(>55 \mathrm{~cm})$, it was the highest in CM and OW treatments and the lowest in PM (Fig. 5b).

\subsection{Biochemical soil properties}

Soil MBC was always the highest in Ap horizon and, regardless of depth, decreased as $\mathrm{CM}>\mathrm{OW}>\mathrm{PM}>\mathrm{IF}$ (Table 4); moreover, it showed larger differences than TOC with regard to fertilizer type. MBC content strongly decreased with increasing soil depth; indeed, it at any horizon was roughly twice over the horizon immediately below (Table 4). SR in Ap horizon (Table 4) behaved as MBC, with $\mathrm{CM}$ and OW higher than PM and IF. Also SR strongly decreased with depth, regardless of fertilizer, and reached comparable values among treatments in the deeper three horizons (Table 4). MQ as well decreased with depth, regardless of fertilizer; for example, at Bw horizon, it was always half compared to rhiA horizon (Table 4). Across the three upper horizons, $C M$ induced the highest $M Q$, while IF the lowest, with $\mathrm{PM}$ and $\mathrm{OW}$ showing intermediate values.

The trend of $\mathrm{qCO}_{2}$ was inversely related to that of $\mathrm{MQ}$; indeed, regardless of fertilizer, it increased with soil depth, and regardless of depth, it increased as $\mathrm{CM}<\mathrm{PM} \sim \mathrm{OW}<\mathrm{IF}$ (Table 4).

\subsection{Microbial community structure}

Total PLFAs content resembled that of MBC as, regardless of fertilizers, it decreased with soil depth, whereas irrespective of depth it was the highest with $\mathrm{CM}$ and the lowest with IF (Table 5). Soils fertilized with PM and OW showed intermediate values.

The percentage of bacteria was higher than that of fungi (Table 5), and except for the BC horizon of PM treatment, it did not change along the soil profiles. Among topsoils, the highest bacteria abundance occurred for IF treatment $(42.1 \%)$. Contrarily to total bacteria, percentages of Gram-positive and Gram-negative bacteria, and consequently their ratio, changed along soil profiles, with the first ones increasing with depth, especially in PM 

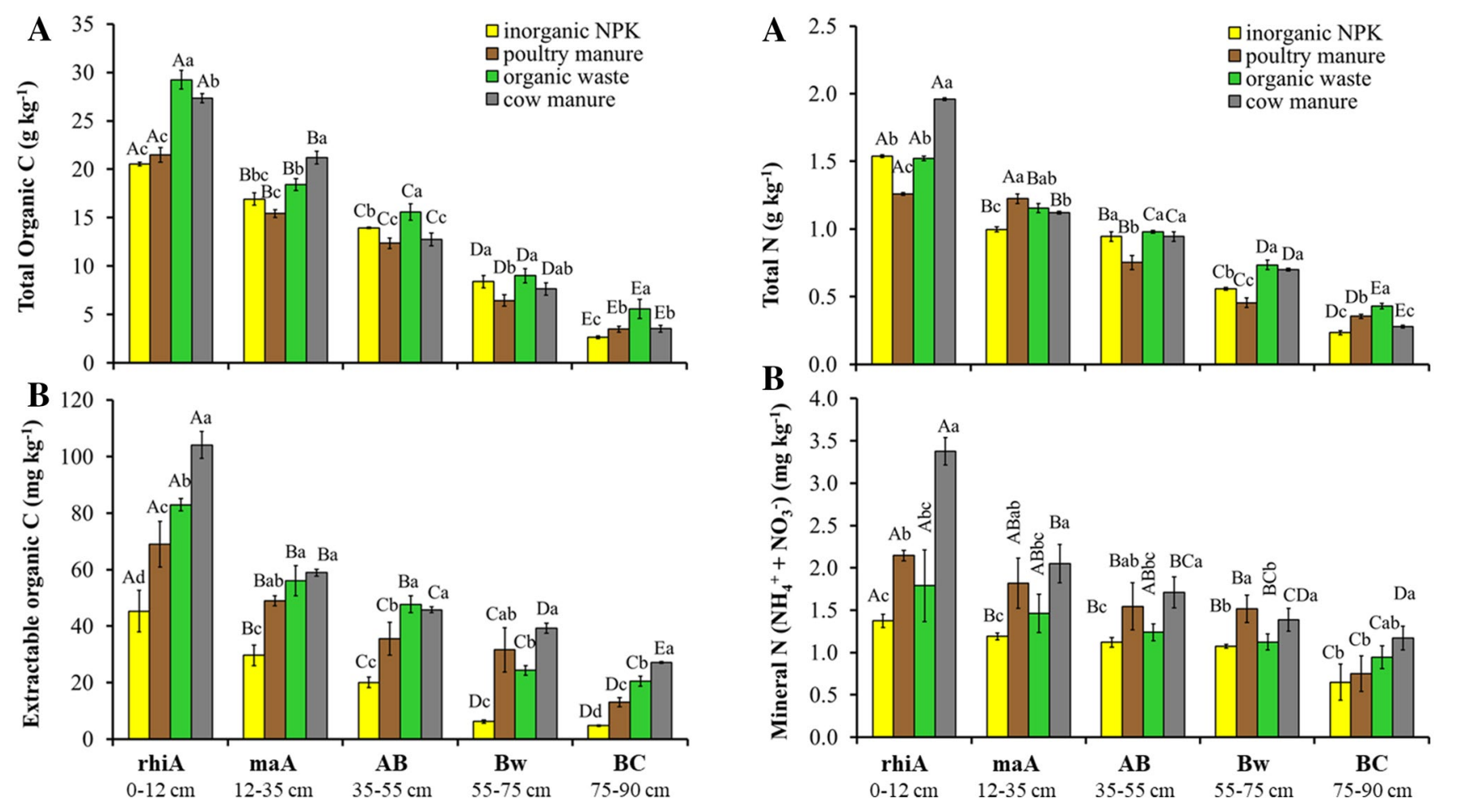

Fig. 2 Total organic C (A) and extractable organic (B) of soils fertilized with four different fertilizers (inorganic fertilizer, NPK; poultry manure; orange waste compost; cow manure). Different upper-case letters indicate significant differences at $P<0.05$ among genetic horizons (depths) within the same soil profile (fertilizer); different lower-case letters indicate significant differences at $P<0.05$ among soil profiles (fertilizers) at the same horizon (depth)

treatment (Table 5). Differently, Gram-negative bacteria decreased with depth, except for PM. Consequently, the ratio Gram-positive to Gram-negative bacteria increased with depth, irrespective of fertilizer. The greatest shift of Gram-positive to Gram-negative bacteria ratio among fertilizers occurred in $\mathrm{Ap}(\mathrm{rhi} \mathrm{A}+\mathrm{maA})$ horizons, where it was the highest in IF treatment and the lowest in CM one (Table 5).

Fungi abundance significantly strongly decreased with depth in all treatments. Irrespective of depth, CM induced the highest $\%$ of fungi, PM and OW intermediate $\%$, while IF the lowest $\%$. As changes in total bacteria were much less pronounced than fungi, the trend of fungi/bacteria ratio $(\mathrm{F} / \mathrm{B})$ reflected that of fungi (Table 5$)$.

\section{Discussion}

\subsection{Shift in chemical soil properties and in organic $C$ content}

The sequence of genetic horizons among orchard plots was similar, thus suggesting that 18 years of different

Fig. 3 Total (A) and mineral (B, extractable ammonium plus nitrate) nitrogen of soils fertilized with four different fertilizers (inorganic fertilizer, NPK; poultry manure; orange waste compost; cow manure). Different upper-case letters indicate significant differences at $P<0.05$ among genetic horizons (depths) within the same soil profile (fertilizer); different lower-case letters indicate significant differences at $P<0.05$ among soil profiles (fertilizers) at the same horizon (depth)

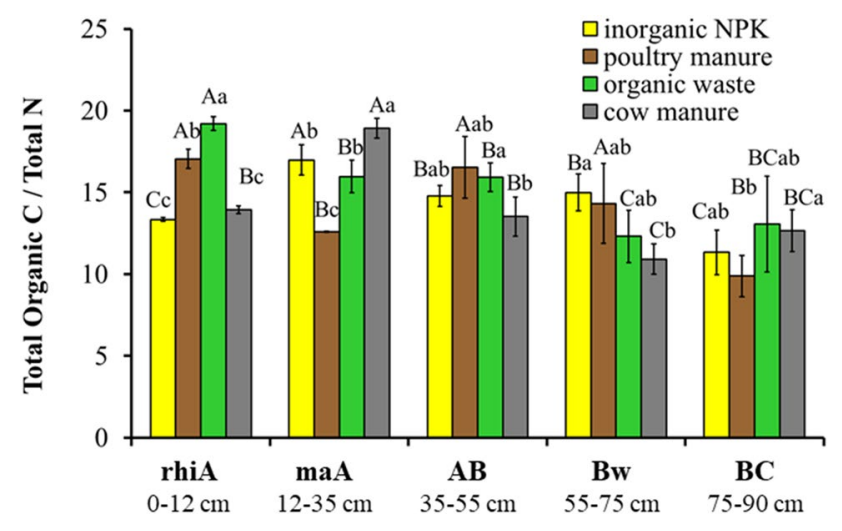

Fig. 4 Total organic C (TOC) to total $\mathrm{N}$ ratio of soils fertilized with four different fertilizers (inorganic fertilizer, NPK; poultry manure; orange waste compost; cow manure). Different upper-case letters indicate significant differences at $P<0.05$ among genetic horizons (depths) within the same soil profile (fertilizer); different lower-case letters indicate significant differences at $P<0.05$ among soil profiles (fertilizers) at the same horizon (depth) 

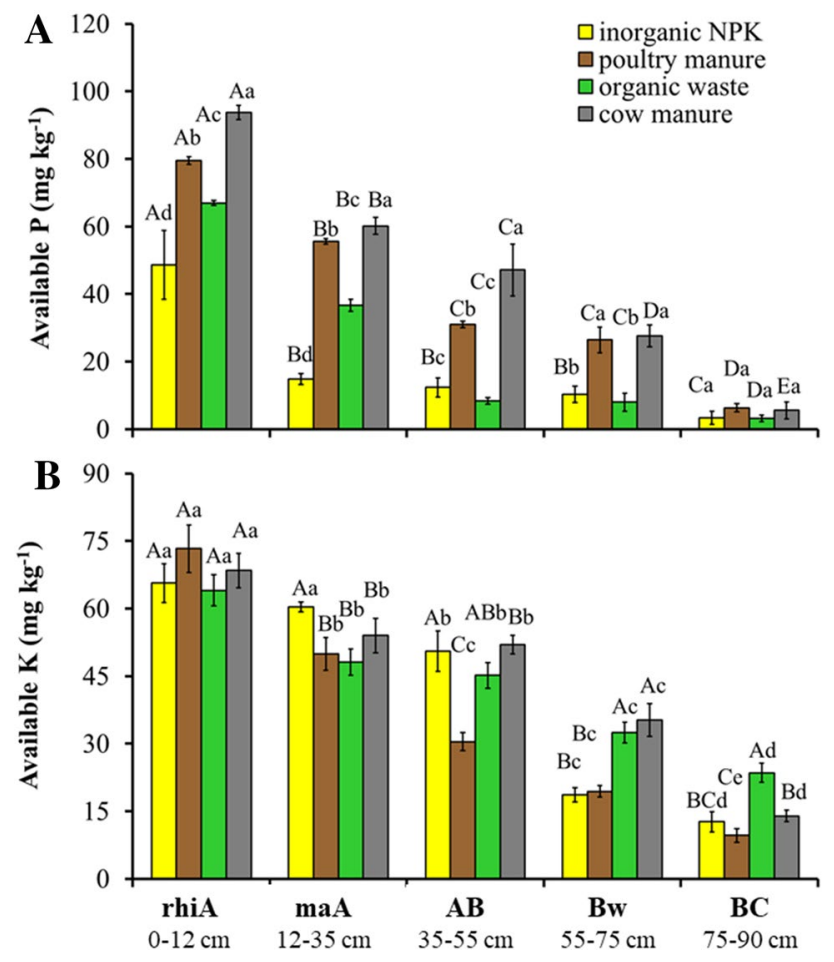

Fig. 5 Available phosphorous (A) and potassium (B) of soils fertilized with four different fertilizers (inorganic fertilizer, NPK; poultry manure; orange waste compost; cow manure). Different upper-case letters indicate significant differences at $P<0.05$ among genetic horizons (depths) within the same soil profile (fertilizer); different lower-case letters indicate significant differences at $P<0.05$ among soil profiles (fertilizers) at the same horizon (depth)

fertilizations did not alter the pedogenesis, probably due to climatic conditions that speed up the mineralization of organic amendments. Due to its morphological characteristics assessed during field survey and based on its physical and chemical properties, the soil was classified as Typic Haplustept [29].

Soil pH was not affected by fertilizers; it increased with soil depth, likely due to the concomitant increase in total carbonates. As the impact on soil reaction by fertilizers was likely the highest in topsoils, the carbonates content was adequate to buffer any acidification or alkalinization process driven by fertilizers.

CEC is a soil chemical parameter rarely investigated in similar studies, although it plays a key role in soil nutrient retention. The highest CEC values in CM and OW treatments, also down to $75 \mathrm{~cm}$ of depth, suggest that such organic fertilizers could enhance the nutrient retention capacity of soils through the soil profile mainly explored by tree roots. Moreover, since soil texture did not show significant differences among horizons at the same depth, it suggests that CEC increase can be ascribed to a greater humification degree of soil organic matter in soil fertilized with $\mathrm{CM}$ and $\mathrm{OW}$.
Soils organically fertilized, as expected in similar environments [38], had higher TOC and EOC than with IF. This likely depended on many concurrent causes: 1 ) direct $C$ supply by organic fertilizers; 2 ) enhanced SOM mineralization rate by microbial activity triggered off with inorganic $\mathrm{N}$ supply [7]; and 3) presumed increase in soil aggregates stability by organic matter supplied. Indeed, mineral fertilization generally reduces soil aggregates stability and, therefore, the protection of SOM, especially in microaggregates $[39,40]$. Instead, organic fertilizers usually improve aggregates stability, thus physically protecting organic $C$ from microbial mineralization [41]. However, organic fertilizers here did not affect TOC content equally. The greater TOC increase with OW and CM, compared to PM and IF, mainly resulted from the highest absolute amounts of TOC supplied since 1995 and calibrated to add the same TN amount (190 $\mathrm{kg} \mathrm{N} \mathrm{ha}^{-1}$, Table 2), what caused the highest $\mathrm{C} / \mathrm{N}$ for OW and CM. Thus, organic substrates in OW and $\mathrm{CM}$ likely were decomposed by micro-organisms more slowly than in PM, because the lower the $\mathrm{C} / \mathrm{N}$ of organic substrates the higher their quality, i.e. the assimilation rate [3]. Here, after nearly 20-year supply of organic fertilizers with different $\mathrm{C} / \mathrm{N}$, the consequent soil $\mathrm{C} / \mathrm{N}$ only in maA horizon reflected that of organic fertilizers, while in rhiA and deeper horizons, the soil $\mathrm{C} / \mathrm{N}$ mostly depended on soil spatial variability (Fig. 4). Thus, in fertilization studies, results about soil $\mathrm{C} / \mathrm{N}$ should be extended to the whole soil profile.

Interestingly, whereas the effects of organic fertilizers on TOC were detectable only down to $35 \mathrm{~cm}$ of soil, their impact on EOC persisted also down to the deepest horizons, being CM and OW more effective than PM and IF in increasing the labile organic $C$ pool in the roots zone explored by orange trees and improving the fruit yield and quality through soil microbial biomass mediation [22]. That extractable $C$ is an early chemical indicator of $C$ changes along the soil profiles better than TOC has been already reported [32].

\subsection{Shift in soil nutrients}

Understanding the macronutrient distribution after different fertilizations in the whole zone explored by roots is crucial for proper crop fertilization, especially if root structures expand up to subsoil. Such understanding and proper estimation led to an efficient supply of fertilizers so it is increasing nutrient uptake and reducing nutrient leaching [22].

With regard to total $\mathrm{N}$, the relatively small significant differences among treatments were expected since it was yearly supplied at the same rate $\left(190 \mathrm{~kg} \mathrm{ha}^{-1} \mathrm{y}^{-1}\right)$. In contrast, mineral $\mathrm{N}$ was higher in topsoil (Ap horizon) up to $75 \mathrm{~cm}$ depth for CM and PM compared to IF and OW, 
Table 4 Biochemical properties of soils fertilized with four different fertilizers (IF, inorganic fertilizer; PM, poultry manure; OC, orange waste compost; $\mathrm{CM}$, cow manure)

\begin{tabular}{|c|c|c|c|c|c|}
\hline Fertilizer & Horizon & $\mathrm{MBC} \mathrm{mg} \mathrm{kg}^{-1}$ & $\begin{array}{l}\text { Soil respira- } \\
\text { tion } \mathrm{mg} \mathrm{CO}_{2}-\mathrm{Cg}^{-1} \mathrm{~d}^{-1}\end{array}$ & MBC/TOC \% & $\mathrm{QCO}_{2} \mathrm{mg} \mathrm{CO}_{2}-\mathrm{Cg}^{-1} \mathrm{MBC} \mathrm{h}^{-1}$ \\
\hline IF & rhiA & $450 \mathrm{Ad}$ & $20.0 \mathrm{Ac}$ & $2.2 \mathrm{Ac}$ & $1.8 \mathrm{Da}$ \\
\hline IF & $\mathrm{maA}$ & $181 \mathrm{BC}$ & $12.4 \mathrm{Bb}$ & $1.1 \mathrm{BC}$ & $2.9 \mathrm{CDa}$ \\
\hline IF & $A B$ & $94 \mathrm{Cc}$ & $7.8 \mathrm{Cb}$ & $0.7 \mathrm{Bd}$ & $3.5 \mathrm{Ca}$ \\
\hline IF & Bw & $63 \mathrm{CDb}$ & 7.1 CDa & $0.8 \mathrm{Bb}$ & 4.8 Ba \\
\hline IF & $\mathrm{BC}$ & $30 \mathrm{Da}$ & $5.2 \mathrm{Ca}$ & 1.1 Ba & $7.4 \mathrm{Aa}$ \\
\hline PM & rhiA & $580 \mathrm{Ac}$ & $22.3 \mathrm{Abc}$ & $2.7 \mathrm{Ab}$ & $1.6 \mathrm{Cab}$ \\
\hline PM & $\mathrm{maA}$ & $246 \mathrm{BC}$ & $13.2 \mathrm{Bb}$ & $1.6 \mathrm{Bb}$ & 2.2 BCab \\
\hline PM & $A B$ & $128 \mathrm{Cb}$ & 8.9 BCab & $1.0 \mathrm{CDC}$ & 2.9 Bab \\
\hline PM & Bw & $91 \mathrm{Ca}$ & $6.9 \mathrm{CDa}$ & $1.4 \mathrm{Ca}$ & $3.2 \mathrm{Bb}$ \\
\hline PM & $\mathrm{BC}$ & $28 \mathrm{Da}$ & 4.8 Da & $0.8 \mathrm{Da}$ & $7.1 \mathrm{Aa}$ \\
\hline OW & rhiA & $732 \mathrm{Ab}$ & 24.1 Aab & $2.5 \mathrm{Ab}$ & 1.4 Db \\
\hline OW & $\mathrm{maA}$ & $338 \mathrm{Bb}$ & $14.3 \mathrm{Bb}$ & $1.8 \mathrm{Bb}$ & $1.8 \mathrm{CDb}$ \\
\hline OW & $A B$ & $190 \mathrm{Ca}$ & 9.3 Cab & $1.2 \mathrm{Cb}$ & $2.0 \mathrm{Cb}$ \\
\hline OW & Bw & $106 \mathrm{Da}$ & $6.9 \mathrm{CDa}$ & $1.2 \mathrm{Cab}$ & $2.7 \mathrm{Bb}$ \\
\hline OW & $\mathrm{BC}$ & $37 \mathrm{Ea}$ & 4.2 Da & $0.7 \mathrm{Ca}$ & 5.0 Aab \\
\hline CM & rhiA & $844 \mathrm{Aa}$ & $25.8 \mathrm{Aa}$ & $3.1 \mathrm{Aa}$ & $1.3 \mathrm{Dc}$ \\
\hline CM & $\mathrm{maA}$ & $485 \mathrm{Ba}$ & 17.3 Ba & $2.3 \mathrm{Ba}$ & $1.5 \mathrm{CDb}$ \\
\hline CM & $A B$ & $198 \mathrm{Ca}$ & $9.7 \mathrm{Ca}$ & $1.6 \mathrm{Ca}$ & $2.0 \mathrm{Cb}$ \\
\hline CM & Bw & $104 \mathrm{Da}$ & $6.9 \mathrm{CDa}$ & $1.4 \mathrm{CDa}$ & $2.8 \mathrm{Bb}$ \\
\hline CM & $B C$ & $41 \mathrm{Ea}$ & 4.2 Da & $1.2 \mathrm{Da}$ & $4.3 \mathrm{Ab}$ \\
\hline
\end{tabular}

Different upper-case letters indicate significant differences at $P<0.05$ among genetic horizons within the same soil profile (fertilizer); different lower-case letters indicate significant differences at $P<0.05$ among soil profiles (fertilizers) at the same depth

Table 5 Total PLFAs (nmoles FA g ${ }^{-1}$ dry soil), main microbial groups (\% of total ELFAs) and their ratio in soils fertilized with four different fertilizers (IF, inorganic fertilizer; PM, poultry manure; OC, orange waste compost; CM, cow manure)

\begin{tabular}{lllllllll}
\hline Fertilizer & Horizon & Total PLFAs & Bacteria & Fungi & Bacteria G+ & Bacteria G- & Bacteria G+/G- & Fungi/Bacteria \\
\hline IF & rhiA & $189.5 \mathrm{Ac}$ & $42.1 \mathrm{Aa}$ & $10.1 \mathrm{Ac}$ & $21.0 \mathrm{Ba}$ & $19.2 \mathrm{Aa}$ & $1.10 \mathrm{Ba}$ & $0.24 \mathrm{Ac}$ \\
IF & $\mathrm{maA}$ & $130.7 \mathrm{Bb}$ & $38.9 \mathrm{Aa}$ & $8.0 \mathrm{Bb}$ & $20.2 \mathrm{Ba}$ & $17.3 \mathrm{Aa}$ & $1.18 \mathrm{Ba}$ & $0.21 \mathrm{ABb}$ \\
IF & $\mathrm{AB}$ & $75.0 \mathrm{Cc}$ & $42.7 \mathrm{Aa}$ & $6.6 \mathrm{Bab}$ & $27.5 \mathrm{Aa}$ & $11.7 \mathrm{Ba}$ & $2.37 \mathrm{Aa}$ & $0.16 \mathrm{BCb}$ \\
IF & $\mathrm{Bw}$ & $40.4 \mathrm{Cb}$ & $37.4 \mathrm{Ab}$ & $3.5 \mathrm{Ca}$ & $24.9 \mathrm{Ab}$ & $12.9 \mathrm{Ba}$ & $2.01 \mathrm{Aa}$ & $0.10 \mathrm{Ca}$ \\
PM & $\mathrm{BC}$ & $230.9 \mathrm{Ab}$ & $33.0 \mathrm{Cc}$ & $15.6 \mathrm{Ab}$ & $15.3 \mathrm{Cbc}$ & $17.0 \mathrm{Aa}$ & $0.92 \mathrm{Cb}$ & $0.47 \mathrm{Ab}$ \\
PM & hiA & $159.9 \mathrm{Bab}$ & $36.3 \mathrm{BCa}$ & $7.9 \mathrm{Bb}$ & $18.0 \mathrm{BCab}$ & $17.7 \mathrm{Aa}$ & $1.03 \mathrm{BCa}$ & $0.22 \mathrm{Bab}$ \\
PM & maA & $108.3 \mathrm{Cb}$ & $38.4 \mathrm{Bab}$ & $4.1 \mathrm{Cb}$ & $22.2 \mathrm{Bb}$ & $17.4 \mathrm{Aa}$ & $1.33 \mathrm{Bb}$ & $0.11 \mathrm{Cb}$ \\
PM & $\mathrm{AB}$ & $37.4 \mathrm{Db}$ & $48.6 \mathrm{Aa}$ & $5.3 \mathrm{Ca}$ & $36.4 \mathrm{Aa}$ & $18.1 \mathrm{Aa}$ & $2.05 \mathrm{Aa}$ & $0.11 \mathrm{Ca}$ \\
OW & $\mathrm{BW}$ & $248.7 \mathrm{Ab}$ & $36.2 \mathrm{Ab}$ & $15.2 \mathrm{Ab}$ & $16.3 \mathrm{Cb}$ & $20.9 \mathrm{Aa}$ & $0.78 \mathrm{Cbc}$ & $0.42 \mathrm{Ab}$ \\
OW & $\mathrm{BC}$ & $150.0 \mathrm{Bab}$ & $37.7 \mathrm{Aa}$ & $8.1 \mathrm{Bb}$ & $18.4 \mathrm{BCab}$ & $19.2 \mathrm{ABa}$ & $0.97 \mathrm{BCa}$ & $0.22 \mathrm{Bab}$ \\
OW & rhi & $116.9 \mathrm{Bab}$ & $37.5 \mathrm{Ab}$ & $8.4 \mathrm{Ba}$ & $20.0 \mathrm{Bc}$ & $17.2 \mathrm{Ba}$ & $1.18 \mathrm{Bb}$ & $0.23 \mathrm{Ba}$ \\
OW & maA & $51.2 \mathrm{Cab}$ & $37.6 \mathrm{Ab}$ & $3.4 \mathrm{Ca}$ & $26.6 \mathrm{Aab}$ & $11.9 \mathrm{Ca}$ & $2.31 \mathrm{Aa}$ & $0.09 \mathrm{Ca}$ \\
$\mathrm{CM}$ & $\mathrm{AB}$ & $274.6 \mathrm{Aa}$ & $35.6 \mathrm{Ab}$ & $20.3 \mathrm{Aa}$ & $14.5 \mathrm{Cc}$ & $21.8 \mathrm{Aa}$ & $0.66 \mathrm{Cc}$ & $0.57 \mathrm{Aa}$ \\
$\mathrm{CM}$ & $\mathrm{Bw}$ & $188.4 \mathrm{Ba}$ & $36.1 \mathrm{Aa}$ & $11.1 \mathrm{Ba}$ & $17.5 \mathrm{BCb}$ & $18.5 \mathrm{ABa}$ & $0.95 \mathrm{BCa}$ & $0.31 \mathrm{Ba}$ \\
$\mathrm{CM}$ & $\mathrm{BC}$ & $137.7 \mathrm{Ba}$ & $36.6 \mathrm{Ab}$ & $8.9 \mathrm{Ba}$ & $20.2 \mathrm{Bbc}$ & $16.7 \mathrm{BCa}$ & $1.22 \mathrm{Bb}$ & $0.24 \mathrm{Ba}$ \\
$\mathrm{CM}$ & rhiA & $86.7 \mathrm{Ca}$ & $37.1 \mathrm{Ab}$ & $4.8 \mathrm{Ca}$ & $25.4 \mathrm{Ab}$ & $13.7 \mathrm{Ca}$ & $2.02 \mathrm{Aa}$ & $0.13 \mathrm{Ca}$ \\
\hline
\end{tabular}

Different upper-case letters indicate significant differences at $P<0.05$ among genetic horizons (depths) within the same soil profile (fertilizer); different lower-case letters indicate significant differences at $P<0.05$ among soil profiles (fertilizers) at the same horizon (depth) 
although much more up to $35 \mathrm{~cm}$. This is important for both nutritional and environmental viewpoints. Indeed, based on origin and chemical nature of the organic fertilizers, their $\mathrm{N}$ mineralization rate likely decreased as $\mathrm{CM}>\mathrm{PM}>\mathrm{OW}$. This since $\mathrm{CM}$ caused the highest soil EOC and available $\mathrm{P}$, while $\mathrm{OW}$ caused much less soil available $\mathrm{P}$, compared to CM and PM (Fig. 5). Remarkably, as the C/N of PM (8.7) was the closest to soil microbial biomass $\mathrm{C} / \mathrm{N}$, likely the proper amount of inorganic $\mathrm{N}$ to be immobilized was achieved even with a relatively slow PM mineralization rate. Certainly, inorganic N from IF was the most promptly used by plant and micro-organisms and/or easily leached from soil since its content was the lowest at any depth. The available $P$, as it essentially derives from the mineralization of organic $\mathrm{P}$, showed a trend similar to that of inorganic $\mathrm{N}$, which in turn derives from mineralization of organic $\mathrm{N}$. Finally, the $\mathrm{K}$ availability reflected that of total $\mathrm{K}$ content, especially in topsoils.

\subsection{Shift in biochemical soil properties}

Microbial biomass acts as both labile nutrient reservoir and catalyst for organic matter decomposition; thus, its dynamics helps to understand soil nutrient fluxes, especially in the root zone of organically fertilized soils [12]. $M B C$ and $S R$, as expected, were much higher in organically fertilized plots in Ap and AB horizons, compared to IF, while in deepest horizons this difference among fertilizers vanished. This is because organic fertilizers can stimulate soil micro-organisms by improving soil physical characteristics and by furnishing readily available sources of major macronutrients [22].

Since soil BD was affected only by depth and not by fertilizer type, the increases in MBC and SR depended likely on the amount and quality of available nutrients from organic fertilizers. Indeed, the highest increases in both $M B C$ and SR occurred with $C M$ since its $C / N$ was the farthest, among other organic fertilizers, from the putative soil microbial biomass average $\mathrm{C} / \mathrm{N}$, i.e. 10 [42], thus suggesting a higher mineralization rate of added $\mathrm{CM}$ for a proper supply of $\mathrm{N}$ and $\mathrm{P}$ to be immobilized $[43,44]$. Moreover, the highest EOC content in $\mathrm{CM}$, i.e. readily available organic substrate, may explain its highest soil MBC.

Both $\mathrm{MQ}$ and $\mathrm{qCO}_{2}$ were affected differently by the four fertilizers, with $\mathrm{qCO}_{2}$ generally increasing with soil depth, whereas $\mathrm{MQ}$ decreasing. $\mathrm{MQ}$ is considered a more sensitive soil health indicator than either MBC or TOC individually [45]. They speculated that the higher the $M Q$, the higher the efficiency of organic matter utilization for microbial growth, due to a higher quality of organic substrates. That the highest $\mathrm{MQ}$ occurred with $\mathrm{CM}$ confirmed its highest quality. Specific respiration $\left(\mathrm{qCO}_{2}\right)$ is considered inversely related to stresses in microbial communities [24]. The microbial metabolic efficiency is supposed to be reflected by their $\mathrm{qCO}_{2}$. Lower $\mathrm{qCO}_{2}$ values with organic fertilizers compared to IF ( $\mathrm{CM}<\mathrm{OW}<\mathrm{PM}<\mathrm{IF})$, coupled with concomitantly higher $M Q$ values $(C M>O W>P M>I F)$, indicate that organic fertilizers energetically favoured microbial communities able to shift more to organic immobilization than mineralization [46]. In other words, with mineral fertilization, the organic substrates were more diverted towards catabolic than anabolic processes, leading to reduced MBC in the long term and thus to lower MQ. Also Böhme et al. [43] found lower $\mathrm{qCO}_{2}$ under manure than mineral NPK fertilization, similar to Badalucco et al. [3], who observed lower $\mathrm{qCO}_{2}$ with organic managements as compared to conventional intensive ones.

The $\mathrm{qCO}_{2}$ increase with depth indicated that the carbon use efficiency was lower in deeper horizons, where oligotrophic conditions generally occur [24]. Thus, when more organic substrates must be catabolized to $\mathrm{CO}_{2}$ to provide needed nutrients, then less organic substrates can be incorporated inside the microbial biomass [46].

\subsection{Shift in abundance of microbial groups}

Both fertilizer type and soil depth significantly affected the content of total PLFAs, whose pattern resembled that of $M B C$, and the abundance of main microbial groups. Indeed, regardless of fertilizers, PLFAs decreased with depth, whereas at any depth, PLFAs generally followed the abundance order $\mathrm{CM}>\mathrm{OW}>\mathrm{PM}>\mathrm{IF}$, i.e. higher with organic than inorganic fertilization [44]. Such patterns, in turn, reflected the availability of both organic and inorganic nutrients determined by fertilizers along the soil profiles.

Main microbial groups were also affected by soil depth and fertilizers, thus confirming that surface microbial communities are larger and more diverse compared to subsurface communities [47]. Similarly, vertical distribution of Gram-negative and Gram-positive bacteria agreed with the previous observations, where microbial communities generally shifted from greater Gram-negative dominance in topsoil to greater Gram-positive dominance in subsoil [27].

Fungal abundance and F/B ratio too, that decreased with soil depth, agreed with similar studies $[25,48]$. Since some soil edaphic properties (texture, $\mathrm{pH}$, electrical conductivity and total carbonates) changed little along the four profiles, the microbial community composition was likely driven by both inorganic and organic nutrients availability that, regardless of soil depth, decreased as $\mathrm{CM}>\mathrm{OW}>\mathrm{PM}>\mathrm{IF}$. Likewise, Griffiths et al. [48] have also found higher fungi and Gram-negative bacteria and lower Gram-positive bacteria with increased organic $C$ availability. Similarly, Zhong et al. [43] found that organic manures 
favoured the Gram-negative bacteria, whereas Gram-positive bacteria flourished better under inorganic fertilization. This is because, generally, Gram-positive bacteria are more able than Gram-negative bacteria in using more complex carbon sources like older SOM, which is more common in deeper soil horizons [49].

The PLFAs signatures of microbial communities reflected the differences in resources availability determined by soil depth and fertilizer type and indicated that fungi and Gram-negative bacteria responded more promptly to nutrient content than other microbial groups. The above considerations agree with patterns of $\mathrm{qCO}_{2}$ that increased with depth, i.e. by decreasing both nutrients availability and fungal PLFAs. Fungi are well known to have higher $C$ use efficiency [50].

\section{Conclusions}

Long-term addition of organic fertilizers compared to IF had strong chemical and biological effects on a Typic Haplustept, and even some differences occurred between the use of animal (poultry or cow) and composted orange wastes organic fertilizers. The changes observed in some chemical properties, mainly organic $C$ pools, mineral $\mathrm{N}$ and CEC up to $75 \mathrm{~cm}$ soil depth, suggest that studies aimed at investigating the impact of fertilization should be extended to the depth explored by plant roots, i.e. generally the whole soil profile.

Soil micro-organisms were stimulated by both the amount and quality of available nutrients supplied by organic fertilizers that, in turn, determined the extent of C use efficiency (low metabolic and high microbial quotients). In this sense, cow manure was the most efficient among the three organic fertilizers tested. The greatest $C$ use efficiency with cow manure was also coupled with a greater amount of fungi that, as widely reported in the literature, use organic $C$ substrates more efficiently than bacteria. Such a shift of microbial community composition coupled with oligotrophic conditions in deeper soil horizons, in turn, determined the patterns of metabolic quotient that increased with depth. The latter issue is of great environmental importance because if on the one hand organic fertilizers contribute to increase organic $C$ in soils, on the other hand fungi better contribute to its storage.

Furthermore, the PLFAs signatures of microbial communities reflected the differences in resources availability determined by soil depth and fertilizer type and indicated that fungi and Gram-negative bacteria responded more promptly to nutrient contents than other microbial groups [51]. Finally, although it was not an aim of this study, it was confirmed that all soil bioindicators related to $\mathrm{C}$ and $\mathrm{N}$ cycling were much more sensitive than total $\mathrm{C}$ and pools, even down to 1-meter depth.

\section{Compliance with ethical standards}

Conflict of interest On behalf of all authors, the corresponding author states that there is no conflict of interest.

\section{References}

1. Cesarano G, De Filippis F, La Storia A, Scala F, Bonanomi G (2017) Organic amendment type and application frequency affect crop yields, soil fertility and microbiome composition. Appl Soil Ecol 120:254-264

2. Rahman MT, Zhu QH, Zhang ZB, Zhou H, Peng X (2017) The roles of organic amendments and microbial community in the improvement of soil structure of a Vertisol. Appl Soil Ecol 111:84-93

3. Badalucco L, Rao M, Colombo C, Palumbo G, Laudicina VA, Gianfreda $L$ (2010) Reversing agriculture from intensive to sustainable improves soil quality in a semiarid South Italy soil. Biol Fertil Soil 46:481-489

4. Laudicina VA, Badalucco L, Palazzolo E (2011) Effects of compost input and tillage intensity on soil microbial biomass and activity under Mediterranean conditions. Biol Fertil Soils 47:63-70

5. Tian J, Lou Y, Gao Y, Fang H, Liu S, Xu M, Blagodatskaya E, Kuzyakov $Y$ (2017) Response of soil organic matter fractions and composition of microbial community to long-term organic and mineral fertilization. Biol Fertil Soils 53:523-532

6. Chen L, Zhang J-B, Zhao B-Z, Xin X-L, Zhao J-H (2014) Carbon mineralization and microbial attributes in straw-amended soils as affected by moisture level. Pedosphere 24:167-177

7. Kätterer T, Börjesson G, Kirchmann H (2014) Changes in organic carbon in topsoil and subsoil and microbial community composition caused by repeated additions of organic amendments and $\mathrm{N}$ fertilisation in a long-term field experiment in Sweden. Agr Ecosyst Environ 189:110-118

8. Diacono M, Montemurro F (2010) Long-term effects of organic amendments on soil fertility: a review. Agron Sustain Dev 30:401-422

9. Bastida F, Selevsek N, Torres IF, Hernández T, García C (2015) Soil restoration with organic amendments: linking cellular functionality and ecosystem processes. Sci Rep 5:15550

10. Fontaine S, Barot S, Barré S, Bdioui P, Mary N, Rumpel C (2007) Stability of organic carbon in deep soil layers controlled by fresh carbon supply. Nature 450:277-280

11. Jacinthe P-A, Shukla MK, Ikemura Y (2011) Carbon pools and soil biochemical properties in manure-based organic farming systems of semi-arid New Mexico. Soil Use Manag 27:453-463

12. Paterson $E$ (2003) Importance of rhizodeposition in the coupling of plant and microbial productivity. Eur J Soil Sci 54:741-750

13. Neff JC, Townsend AR, Gleixner G, Lehman SJ, Turnbull J, Bowman WD (2002) Variable effects of nitrogen additions on the stability and turnover of soil carbon. Nature 419:915-917

14. Huang S, Zhang WJ, Yu XC, Huang QR (2010) Effects of longterm fertilization on corn productivity and its sustainability in an Ultisol of southern China. Agric Ecosyst Environ 138:44-50 
15. Laudicina VA, Barbera V, Gristina L, Badalucco L (2012) Management practices to preserve soil organic matter in semiarid Mediterranean environments. In: Björklund PA et al (eds) Soil organic matter: ecology, environmental impact and management. Nova Science Publishers, Inc., New York, pp 39-61

16. Lou Y, Xu M, Wang W, Sun X, Liang C (2011) Soil organic carbon fractions and management index after $20 \mathrm{yr}$ of manure and fertilizer application for greenhouse vegetables. Soil Use Manag 27:163-169

17. Khan SA, Mulvaney RL, Ellsworth TR, Boast CW (2007) The myth of nitrogen fertilization for soil carbon sequestration. J Environ Qual 36:1821-1832

18. Mulvaney RL, Khan SA, Ellsworth TR (2009) Synthetic nitrogen fertilizers deplete soil nitrogen: a global dilemma for sustainable cereal production. J Environ Qual 38:2295-2314

19. Benbi DK, Brar K, Toor AS, Sharma S (2015) Sensitivity of labile soil organic carbon pools to long-term fertilizer, straw and manure management in rice-wheat system. Pedosphere 25:534-545

20. Yu HY, Ding WX, Luo JF, Donnison A, Zhang JB (2012) Long-term effect of compost and inorganic fertilizer on activities of carboncycle enzymes in aggregates of an intensively cultivated sandy loam. Soil Use Manag 28:347-360

21. Geisseler D, Scow KM (2014) Long-term effects of mineral fertilizers on soil microorganisms - a review. Soil Biol Biochem 75:54-63

22. Liu E, Yan C, Mei X, He W, Bing SH, Ding L, Liu Q, Liu S, Fan T (2010) Long-term effect of chemical fertilizer, straw, and manure on soil chemical and biological properties in northwest China. Geoderma 158:173-180

23. Fontaine S, Barot S (2005) Size and functional diversity of microbe populations control plant persistence and long-term soil carbon accumulation. Ecol Lett 8:1075-1087

24. Laudicina VA, Palazzolo E, Piotrowska-Długosz A, Badalucco L (2016) Soil profile dismantlement by land levelling and deep tillage damages soil functioning but not quality. Appl Soil Ecol 107:298-306

25. Fierer N, Schimel JP, Holden PA (2003) Variations in microbial community composition through two soil depth profiles. Soil Biol Biochem 35:167-176

26. Gelsomino A, Petrovičová B, Vecchio G, Laudicina VA, Badalucco $L$ (2013) Chemical, biochemical and microbial diversity through a Pachic Humudept profile in a temperate upland grassland. Agrochimica 67:214-232

27. Blume E, Bischoff M, Reichert J, Moorman T, Konopka A, Turco R (2002) Surface and subsurface microbial biomass, community structure and metabolic activity as a function of soil depth and season. Appl Soil Ecol 592:1-11

28. Fang C, Moncrieff JB (2005) The variation of soil microbial respiration with depth in relation to soil carbon composition. Plant Soil 268:243-253

29. Soil Survey Staff (2015) Illustrated guide to soil taxonomy, version 2. U.S. Department of Agriculture, Natural Resources Conservation Service, National Soil Survey Center, Lincoln, Nebraska

30. Olsen S, Cole C, Watanabe F, Dean L (1954) Estimation of available phosphorus in soils by extraction with sodium bicarbonate. USDA Circular Nr 939, Washington, DC. pp 1-19

31. Vance ED, Brookes PC, Jenkinson DS (1987) An extraction method for measuring soil microbial biomass C. Soil Biol Biochem 19:703-707

32. Laudicina VA, Palazzolo E, Badalucco L (2013) Natural organic compounds in soil solution: potential role as soil quality indicators. Curr Org Chem 17:2991-2997

33. Wu Y, Ding N, Wang G, Xu J, Wu J, Brookes PC (2009) Effects of different soil weights, storage times and extraction methods on soil phospholipid fatty acid analyses. Geoderma 150:171-178
34. Frostegård A, Bååth $E$ (1996) The use of phospholipid fatty acid analysis to estimate bacterial and fungal biomass in soil. Biol Fertil Soils 22:59-65

35. Zelles $L$ (1997) Phospholipid fatty acid profiles in selected members of soil microbial communities. Chemosphere 35:275-294

36. Zanella A, Ponge J-F, Fritz I, Pietrasiak N, Matteodo M, Nadporozhskaya M, Juilleret J, Tatti D, Le Bayon R-C, Rothschild L, Mancinelli R (2018) Humusica 2, article 13: para humus systems and forms. Appl Soil Ecol 122:181-199

37. Zanella A, Ponge J-F, Jabiol B, Sartori G, Kolb E, Gobat J-M, Le Bayon R-C, Aubert M, De Waal R, Van Delft B, Vacca A, Serra G, Chersich S, Andreetta A, Cools N, Englisch M, Hager H, Katzensteiner K, Brêthes A, De Nicola C, Testi A, Bernier N, Graefe U, Juilleret J, Banas D, Garlato A, Obber S, Galvan P, Zampedri R, Frizzera L, Tomasi M, Menardi R, Fontanella F, Filoso C, Dibona R, Bolzonella C, Pizzeghello D, Carletti P, Langohr R, Cattaneo D, Nardi S, Nicolini G, Viola F (2018) Humusica 1, article 4: terrestrial humus systems and forms-specific terms and diagnostic horizons. Appl Soil Ecol 122:56-74

38. Melero S, Ruiz Porras JC, Herencia JF, Madejón E (2006) Chemical and biochemical properties in a silty loam soil under conventional and organic management. Soil Tillage Res 90:162-170

39. Herencia JF, Garcìa-Galavìs PA, Maqueda C (2011) Long-term effect of organic and mineral fertilization on soil physical properties under greenhouse and outdoor management practices. Pedosphere 21:443-453

40. Mäder P, Fließbach A, Dubois D, Gunst L, Fried P, Niggli U (2002) Soil fertility and biodiversity in organic farming. Science 296:1694-1697

41. Canali S, Di Bartolomeo E, Trinchera A, Nisini L, Tittarelli F, Intrigliolo F, Roccuzzo G, Calabretta ML (2009) Effect of different management strategies on soil quality of citrus orchards in Southern Italy. Soil Use Manag 25:34-42

42. Cleveland CC, Liptzin D (2007) C:N: P stoichiometry in soil: is there a "Redfield ratio" for the microbial biomass? Biogeochemistry $85: 235-252$

43. Böhme L, Langer U, Böhme F (2005) Microbial biomass, enzyme activities and microbial community structure in two European long-term field experiments. Agric Ecosyst Environ 109:141-152

44. Zhong W, Gu T, Wang W, Zhang B, Lin X, Huang Q, Shen W (2010) The effects of mineral fertilizer and organic manure on soil microbial community and diversity. Plant Soil 326:511-522

45. Anderson JPE, Domsch KH (1989) Ratios of microbial biomass carbon to total carbon in arable soils. Soil Biol Biochem 21:471-479

46. Dilly O (2005) Microbial energetics in soils. In: Buscot F et al (eds) Microorganisms in soils: roles in genesis and functions. Springer, Berlin, pp 123-138

47. Fritze H, Pietikainen J, Pennanen T (2000) Distribution of microbial biomass and phospholipid fatty acids in Podzol profiles under coniferous forest. Eur J Soil Sci 51:565-573

48. Griffiths B, Ritz K, Ebblewhite N, Dobson G (1999) Soil microbial community structure: effects of substrate loading rates. Soil Biol Bioche. 31:145-153

49. Kramer C, Gleixner G (2008) Soil organic matter in soil depth profiles: distinct carbon preferences of microbial groups during carbon transformation. Soil Biol Biochem 40:425-433

50. Six J, Frey SD, Thiet RK, Batten KM (2006) Bacterial and fungal contributions to carbon sequestration in agroecosystems. Soil Sci Soc Am J 70:555-569

51. de Menezes AB, Richardson AE, Thrall PH (2017) Linking fungalbacterial co-occurrences to soil ecosystem function. Curr Opin Microbiol 37:135-141

Publisher's Note Springer Nature remains neutral with regard to jurisdictional claims in published maps and institutional affiliations. 